\title{
TOURIST REVIEWS AS A LINGUISTIC PHENOMENON IN TRAVEL BLOGGING
}

Summary. The article discusses the development of blogging platform as a new genre of digital communication in Kazakhstan. Digital communication have been evolving in the world with rapid speed attracting millions of communicants from all corners of the planet calling them for dialogue. Thanks to digital communication, both addressees and addressers are sharing and gaining new knowledge in different spheres of life according to their interests, which was not available before. Author introduces the first bloggers in Kazakhstan, who introduced this new media and highlights the sustainable development of the tourism industry as well as the creation of language of tourism. The use of digital technologies contributes to the development of tourism communications in new media, the study of which is of great interest to linguists. Author mentions the importance of investigating the language usage in travel blogging, particularly media texts in the form of tourist reviews. Linguists in Kazakhstan before have not studied tourist reviews. Therefore, the author carried out the linguistic analysis of the tourist reviews relating to Kazakhstan and language picture of Kazakhstan. Tourist reviews are taken from the world's largest travel platform tripadvisor.com. The mission of the TripAdvisor is to help travelers around the world plan and book the perfect trip. The main goal is to find out what tourists think about the language picture of Kazakhstan and its tourism potential and to study language specifics of tourist reviews. Language of online reviews like on tripadvisor.com serve as a source for discourse analysis where linguists research how tourists use language and other symbolic resources to create a review. The author tried to focus on the sections "Things to do" and "hotels" on tripadvisor.com.

Key words: blogging, digital communication, travel blogs, linguistic aspect, tourist reviews.

Formulation of research question and its connection with crucial scientific and practical tasks. It is remarkably noticed that tourism turned into a driver of socio-economic development all over the world in the twenty first century and Kazakhstan as the country of "Great steppes" is not an exception. Without doubt, tourism is a priority for Kazakhstan due to its tourism potential. Over the past ten years, a big number of activities have been organized in Kazakhstan to accelerate the development of the tourism sector.

One of the brilliant examples of this is hosting the international specialized exhibition "Astana EXPO 2017", where 115 countries participants, twenty-five international organizations took part in the exhibition. Twenty-eight heads of states, thirty-six prime ministers and seventy ministers of foreign affairs visited the exhibition. 5,4 million people visited the capital during the exhibition [1].

Statement of objectives and research tasks. Language of tourism has been the focus to many investigations due to the new culture of tourism that has no borders in the time of dynamically growing information technologies. In the tourism industry, travel blogging used as an effective and distinctive media platform to promote tourism in the world. As it is known nowadays, linguistics shows much interest to the problems of real communication and nowadays blogging has definitely become a field for interaction for everyone on the internet.

Definitely, blogging is the youngest genre of internet discourse in comparison to other genres like chats, forums etc. In Kazakhstan, it has not been the focus of linguistic studies before. It is in its infancy state.

Analysis of research publications; examination of unstudied problem aspects. Blogging is properly investigated by western scholars as C. Miller and D. Sheperd (2004), S. Bonus and E. Wright (2005) and linguists from CIS countries as I.N. Rozina (2005), E.I. Goroshko (2007), O.V. Lutovinova (2009), L.Y Schipitsina (2009) etc. These scientists studied blogging from different aspects.

Presentation of materials with justification of obtained results. E.I. Goroshko one of the first who has spoken about internet linguistics. The scholar defines the internet linguistics as "the functioning of language in the field of internet communication" [2].

O.V. Lutovinova relates blogging as a genre of internet communication. Researcher defines a blog in two ways first, as a "web page or a site with a set of links to other sites", second, as a "a news feed with the ability to add links on the subject and small comments" [3, p. 198].

Observing several blogs, we noticed that blog is usually run by three type of communicants:

1) those who write about their favorite hobbies or business;

2) celebrities;

3) those who make money in blogging.

Currently linguistics are researching different speech genres within certain institutional discourses. Tourism discourse is fluid and dynamically developing types of institutional discourse, since the industry of tourism operates with constantly updated technological developments.

According to British scientist John Urry, tourism is a complex phenomenon with psychological, sociological and cultural dimensions [4]. Thanks to this industry communicators around the world are sharing culture, establishing new contacts, and gaining new knowledge.

Nowadays the representatives of new media - travel bloggers play significant role to promote the tourism sector of each country. Firstly, it is essential to mention the start of blogging process in Kazakhstan.

Askhat Yerkimbay can be concidered as the founder of Kazakh blogosphere. Since 2007 he has been involved in the promotion of Kazakh bloggers and to create quality content to recipients. He is 
the executive director of "Minber" center for supporting journalists, editor of the Kazakh section of the site www.neweurasia.net.

Arshat Orazov is also the first, who contributed much to the development of blogging in Kazakhstan. He is the founder of the first blog platform Kerekinfo.kz in our country. His name is well known among Internet users. He contributes greatly to the development of Kazakh-language content in the blogosphere. $\mathrm{He}$ is the author of several Internet projects in the country, an IT expert, blogger, fan, sports commentator, media lecturer, freelancer.

Thanks to the advances in communication technology, it is getting easier for everyone to publish their thoughts online about the places they have visited. In this case, TripAdvisor is one of the popular platform where speech genre of "online tourist review" is designed type of text containing the author's assessment of travel and related services posted on the network. There is a feedback for tourist's reviews on tripadvisor.com. It is interesting to study the language embodiment between the author of tourist review and travel agents. This function makes it more touristfriendly. Everyone who is planning a trip to a definite country now makes it as a habit first to read reviews. Positive reviews usually contain positive adjectives and epithets creating positive image of Kazakhstan. For example,

\section{Best wav to see Nur-Sultan!}

Taking a private tour of Nur-Sultan was the BEST thing we ever did (other than attend the 2019 Senior World Wrestling Championships). Our guide took us to the key sights and gave us a history of the making of the city. Since every ticket entrance was included in the price, we didn't have to stand in line to wait. We learned so much by visiting the Baiterek Tower, the National Museum, Hazret Sultan Mosque, and the Expo 2017 that made our trip to Kazakhstan a memorable one! (tripadvisor.com).

\section{Response}

Thank you very much for your review!

It is big pleasure for us you to call your Nur Sultan Day Tour as the best :)! One of our goals is to provide comfortable services showing the beauty of our country.

We will be glad to serve you again in any place in Kazakhstan. Please feel free to contact us, we are available 24/7 (tripadvisor. com).

From the above online review, it is clearly seen that the review contains the best tourist attractions in Nur-Sultan city. The author wrote the word "best" with capital letters in order to highlight and to persuade the addressees.

\section{Kazakhstan a must}

The most beautiful thing I have ever seen Stunning at night And lift to the top. An absolute must I came to see and hear a Kazakhstanie singer. DIMASH Also did a lot of sightseeing. Coming back next year Need to see Almaty So much to see people are so helpful and friendly.

\section{Response}

Thank you for visiting Kazakhstan and your feedback on our services!

It is a pleasure to know you enjoyed your Nur-Sultan sightseeing tour with lifting up to Baiterek. Thank you for sharing your pictures!

We are proud our singer Dimash was the reason of your visit! We will be happy to welcome and serve you in wonderful Almaty. Please feel free to contact us 24/7.

Above illustrated tourist review shows that for some tourists Kazakhstan' image is represented with famous Kazakh singer
Dimash Kudaibergen. Review contains emotional lexemes like "stunning" and "need" and to show emotions these lexemes are written with capital letters. The feedback from tourist manager creates tourist-friendly atmosphere that is ready to help tourists seven days a week and twenty-four hours a day. Regarding the genre of "online tourist review", the main exchange messaging occurs between status equal in terms of institutional discourse, by tourists.

\section{2 hours layover in Nur-Sultan}

NurSurtan itself is an extremely safe city and I would have no problems recommending it to be explored alone at any time day or night.

\section{Monument to Khan Kenesary}

Need to see also. Really nice area. Also you can walk with your family also night time. Really safety area. I'm sure that you will catch amazing pictures.

According to many reviews, Kazakhstan is represented as a safe place for tourists.

One of the parameter that occurs in tourist reviews is the favorable location of the tourist destination or a place of residence. This value is displayed in the reviews "close/far" and "convenient/inconvenient to get":

\section{Example 1}

Just amazing, so beautiful to see, the best way if you have a car and you can drive less than 1 hour from Almaty, otherwise you can get a taxi on app Yandex and tell the driver to wait for you there, I spent more than 2 hours there.

\section{Example 2}

Beautiful location with breathtaking views. You reach here after driving almost half an hour. Worth Visiting (About Big Almaty lake).

We looked through the the reviews about Rixos Almaty Hotel on tripadvisor.com. This luxury 5-star hotel is located in central Almaty. Nine hundred forty eight reviews have been written relating this hotel. Among reviews, positive comments are more salient than negative comments. Six hundred fifty one reviews have very positive language units. Two hundred twenty two tourists evaluated like "very good" and forty-seven tourists evaluated as "average". First, let us look through very positive reviews. All reviews have a headline.

\section{Beautiful Property, Centrally located}

What a grand view when you enter the Hotel, Beautiful common area in the centre to chill with a great bar to spend time at. Lavish breakfast buffet provided along with impeccable service by staff all around the hotel.

The spa, Turkish baths, steam \& sauna were also beautifully designed spaces with great ambience. Definitely one of the best places to stay around the center.

Communication within online tourist reviews do not follow formal business style. It is in:

\section{- Conversational style}

For example,

Ethno-village

A simple car ride to the mountain region to a Yert village with the very capable Mirana.

The snack in the Yert with details of Kazakh life for families and the chance to ask questions of their life was beautiful. The family dancing all together having fun was magical. The horse riding culture, Wrestling on horse back catching the bride and riding a Kazakh horse up close and personnel was fabulous, all in a snow capped mountain setting. 
Don't expect polished tourist trashy events, but true from the heart with their children proud of their beautiful movement and strong practical environment friendly living.

Blown away.

\section{Beautiful place, but Kaindy-Lake is more "wow"}

We spent a very nice time there camping at the other end of the lake. Hiked the 4,2 $\mathrm{km}$ with small kids. Nice hike. Kids loved playing in the streams and being out in the nature.

\section{- Publicistic style}

Obviously one of the world's best Operas

The group of performers were just splendid in singing. The performances were rich in traditions and culture with western fusions too. A person with minimal taste in music could also enjoy the show rich in arts and humour, Most shows end with a splendid cocktail serving.

\section{- Literary style}

Third biggest opera in the world

Performed in June 2017. It is a dreamland for every artist to perform. Beautiful aesthetics, excellent acoustics and extremely well equipped. Royal looking seating and amazing facilities for the technical support (About Astana opera).

\section{Asian Grand Canyon}

Impressive nature's monumental walk. Long walk different kinds of stone, colorful patterns. It is possible to stay overnight in the end of the canyon and enjoy the sound of in the mountain cup (About Asian Grand Canyon).

Review as a complex genre combines genres that are opposite in sign in a typical case, praise/censure. The presence of a "twopart structure" in book reviews feedback and suggestions are extremely rare, however most online travel reviews have an ambivalent rating:

Really nice hotel. Rooms are big, and very well kept. Bathroom also big with floor heating, shower \& separate bath tub. Not cheap, but really good quality. Staff do not all understand English but are very friendly (About Rixos Almaty Hotel).

Studying "online travel reviews" from linguistic side especially how tourists narrate their experiences it is noticed that generally tourists have written positive reviews as a safe and tourist-friendly destination.

As the summary of the article it would be relevant to use the travel quote that comes from a philosopher Aurelius Augustine, "The world is a book, and those who do not travel read only a page", is like an inspirational phrase for a big audience today. If someone stays in one place all his/her life, he/she can never turn a page and not experience new and exciting things. Only travelling allows you to "read page after page" fully immersing yourself in "the book" that is life. The future of travel blogging is promising and it will be always stay as a discussible theme among linguists.

\section{References:}

1. History of EXPO. URL: https://expo2017astana.com/en/page_id=56.

2. Горошко Е.И. Лингвистика Интернета: формирование дисциплинарной парадигмы. Жанры и типы текста в научном и медийном дискурсе. 2007. Вып. 5. С. 223-237.

3. Лутовинова О.В. Лингвокультурологические характеристики виртуального дискурса. Волгоград : Изд-во ВГПУ «Перемена», 2009. 447 с.

4. Urry J. The Tourist Gaze. $2^{\text {nd }}$ ed. London : Thousand Oaks ; New Delhi : Sage, 2002. $180 \mathrm{p}$.

5. Tripadvisor.com. URL: https://www.tripadvisor.com/Attractionsg293943-Activities-Kazakhstan.html.

Куркімбаєва А. М. Туристичні огляди як лінгвістичний феномен у туристичних блогах

Анотація. У статті розглядається розвиток платформи блогів як нового жанру цифрового спілкування в Казахстані. Цифрова комунікація розвивається у світі 3 великою швидкістю, залучає мільйони комунікантів 3 усіх куточків планети, закликає їх до діалогу. Завдяки цифровому спілкуванню і адресати, і адресанти діляться та отримують нові знання в різних сферах життя відповідно до своїх інтересів, чого раніше не було. Автор розглядає перших блогерів у Казахстані, які представили цей новий засіб масової інформації та підкреслили сталий розвиток туристичної галузі, а також створення мови туризму. Використання цифрових технологій сприяє розвитку туристичних комунікацій у нових засобах масової інформації, вивчення яких становить інтерес для лінгвістів. Автор зазначає важливість дослідження мови туристичних блогів, зокрема медіатекстів у вигляді туристичних оглядів. Лінгвісти в Казахстані раніше не вивчали туристичні огляди. Тому автор здійснив лінгвістичний аналіз туристичних оглядів, що стосуються Казахстану, і мовної картини Казахстану. Огляди туристів взяті з найбільшої світової туристичної платформи tripadvisor.com. Місія TripAdvisor - допомогти туристам у всьому світі спланувати та забронювати ідеальну подорож. Основна мета-з'ясувати, що думають туристи про мовну картину Казахстану та його туристичний потенціал, а також вивчити мовну специфіку туристичних оглядів. Мова онлайн-оглядів, наприклад, на tripadvisor.com слугує джерелом для аналізу дискурсу, де лінгвісти досліджують, як туристи використовують мову та інші ресурси для створення оглядів. Автор спробував зосередитися на розділах «Чим зайнятися» та «Готелі» на tripadvisor.com.

Ключові слова: блоги, цифровий зв'язок, туристичні блоги, лінгвістичний аспект, туристичні огляди. 